\title{
Música que forma cidadãos
}

Resumo: O grupo artístico Meninos do Morumbi (MM), composto de jovens paulistanos e criado dentro da organização de mesmo nome, atende mais de três mil crianças, a maioria de comunidades de baixa renda. Hoje, a maior parte da sustentabilidade da entidade vem das apresentações realizadas pelos próprios jovens, em eventos dentro e fora do Brasil. Considerado projeto-modelo no Brasil pela Unesco, os Meninos do Morumbi já receberam prêmios de instituições como Unicef, Ministério da Cultura, Câmara Americana de Comércio e Rotary International, entre muitos outros. Neste depoimento dado à revista Comunicação \& Educação, Flávio Pimenta, maestro e fundador do MM, fala sobre a história e as conquistas do projeto norteado pelo equilíbrio entre trabalho comunitário e atuação profissional.

Palavras-chave: Meninos do Morumbi, comunidade, gestão, educação, comunicação.
Abstract: The artistic group called Meninos do Morumbi (Boys from Morumbi), composed by youths from São Paulo and created inside the organization that has the same name, assists more than three thousand children, most of them from low income communities. Nowadays, most of the entity maintenance comes from the presentations accomplished by those youths, in events inside and outside Brazil. Considered as model project in Brazil by UNESCO, the Meninos do Morumbi (Boys from Morumbi), have already received prizes from institutions as UNICEF, Culture Ministry, Trade American Camera and Rotary International, among many others. In this deposition given to the magazine Communication \& Education, Flávio Pimenta, MM conductor and founder, tells us about the history and the project conquests guided by the balance between community work and professional performance.

Keywords: Meninos do Morumbi (Boys from Morumbi), community, administration, education, communication.

Quem já assistiu a uma apresentação dos Meninos do Morumbi, grupo artístico composto de jovens paulistanos e criado dentro da organização de mesmo nome, não imagina a extensão do trabalho social do qual participam. Atendendo mais de três mil crianças, a maioria de comunidades de baixa renda em São Paulo, a entidade oferece gratuitamente cursos de educação musical, acompanhamento escolar, refeições e a oportunidade de realizar shows e gravações com grandes nomes do universo artístico nacional e internacional. O maestro e fundador Flávio Pimenta, porém, não gosta de relacionar seu trabalho à benemerência ou filantropia. Acima de tudo, ele se intitula um band leader - função que sempre exerceu profissionalmente com alunos e grupos musicais. Essa é a filosofia que implantou na gestão e nas atividades desenvolvidas pela organização. Hoje, a maior parte da sustentabilidade da entidade vem das apresentações realizadas pelos próprios jovens, em eventos dentro e fora do Brasil. De acordo com Flávio, é a qualidade artística que possibilita à organização continuar a desenvolver seus trabalhos sociais e educacionais.

A fórmula tem alcançado reconhecimento. Considerado pela Unesco projeto-modelo no Brasil, os Meninos do Morumbi já receberam prêmios de instituições como Unicef, Ministério da Cultura, Câmara Americana de Comércio e Rotary International, entre 
comunicação \& educação • Ano XV • número 2 - maio/ago 2010

muitos outros - além de terem se apresentado ao lado de orquestras nacionais e internacionais e artistas de estilos variadas, como Orquestra Jovem das Américas, grupo Fala Mansa, Sandra de Sá e Marcelo Bratke. No depoimento dado à revista Comunicação \& Educação, Pimenta fala sobre a história e as conquistas do projeto norteado pelo equilíbrio entre trabalho comunitário e atuação profissional.

Quando comecei o trabalho dos Meninos no Morumbi, em 1996, estava me preparando para viver fora do Brasil. Tenho uma casa no bairro do Morumbi, em São Paulo, mas estava de mudança para os Estados Unidos a convite de algumas fábricas de instrumentos musicais com as quais trabalhava. Um dia, em minhas andanças pelo bairro, vi três crianças nadando nas lagoas sujas em frente ao Palácio do Governo do Estado. Hoje o lugar é uma praça muito bonita, mas na época era um esgoto a céu aberto, onde as crianças das favelas costumavam nadar. Como estou no bairro há muitos anos, conheço o histórico da região e sei de mortes de crianças por afogamento ali, além do assédio de pedófilos. E os meninos estavam lá em horário escolar, com os dentes cariados, micoses e pés no chão. Fiquei comovido com a cena, fui até eles e disse: "Olha, eu sou baterista e estou montando uma banda. Vocês não querem tocar comigo?”. Na verdade, eu não queria montar banda nenhuma. Foi apenas uma forma de não dizer a eles que eu queria ensinar alguma coisa, porque achei que eles não iriam topar. Quando falei em tocar tambor, um deles até disse: "Ah, eu toco".

Como eu estava pronto para me mudar, já tinha desativado minha escola de música e o estúdio de gravação. Mantinha apenas alguns trabalhos com alunos que estavam comigo há anos. Então iniciei as aulas com esses meninos também. Depois que começamos, alguns dos meus alunos e músicos profissionais começaram a tocar junto com eles. Os meninos, por sua vez, trouxeram amigos. Um mês depois

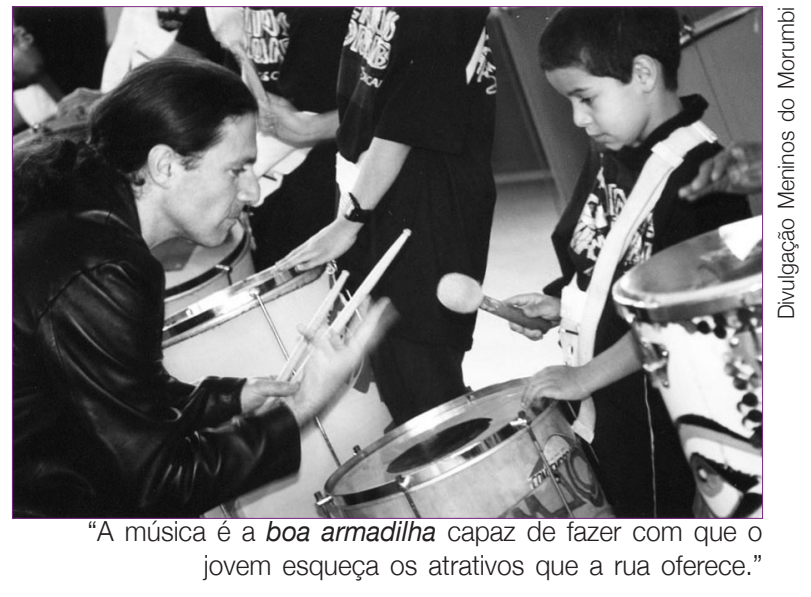
eu já tinha doze, treze alunos.

Então uma amiga jornalista me convidou para dar uma entrevista na rádio onde trabalhava, falando sobre as aulas gratuitas para crianças da favela. Depois disso, a equipe do serviço SOS Criança, uma instituição para menores em situação de rua, me procurou para dar aulas também para os jovens que eles atendiam.

Em meados de maio, já eram cerca de sessenta crianças. O próximo passo foi a aproximação com a Febem, que atendia menores infratores e também se interessou pelo projeto. Nessa época, os ensaios aconteciam na rua e nossa sede era a minha casa. Eu recebia todos na cozinha, sempre com lanches e refeições. Desde o início, alimentar os jovens fez parte dos nossos programas. Quando 
Música que forma cidadãos • Flávio Pimenta

as Kombis do SOS Criança atrasavam, eu comprava pizza e todo mundo comia sentado na calçada. O quarteirão da minha casa ficava cheio de gente, porque vinham 100 crianças e mais 200 amigos convidados. Os moradores dos prédios da frente odiavam, jogavam tomates e ovos. Diziam: "Eu compro um apartamento de 300 mil dólares e você traz molecada para fazer barulho aqui? Não consigo ouvir a televisão, não consigo atender ao telefone". Eu respondia: "Mas a gente só ensaia duas vezes por semana. É um trabalho social”. Fiz uma carta para os moradores dos prédios explicando o projeto. Mesmo assim, foi uma luta. Passei a evitar tocar sempre nos mesmos lugares. Saía como um desfile até a pracinha... lá tomávamos lanche, depois voltávamos tocando.

Fui me envolvendo cada vez mais com o trabalho. Quando chegou o mês de julho, data da minha viagem, acabei desistindo da ideia de ir para os Estados Unidos. Aluguei um sobrado ao lado da minha casa, como sede para o projeto, e ali começou a história.

\section{DA FAVELA PARA O ESTÚDIO: PROJETO DE VIDA EXPANDIDO}

Nesse mesmo período eu tinha um aluno cujo pai, senhor Gino, havia sido o melhor amigo do meu pai - e que ainda hoje é presidente da Federação de Obras Sociais (FOS). Quando ele soube do meu trabalho, veio conhecer e disse: "O mais difícil você consegue, que é juntar todas essas crianças. Temos que fazer disso uma instituição". Então ele me ajudou a planejar um estatuto, enquanto a FOS começou a contribuir com o lanche das crianças e com o aluguel da casa. Até então eu estava comprando instrumentos, lanches e mandando fazer camisetas com o meu próprio capital. Com a contribuição da FOS, viramos instituição.

Depois vieram as parcerias com o Projeto Travessia, que também atendia crianças em situação de rua. O Travessia trouxe o Projeto Axé, que nos ofereceu uma consultoria extremamente competente no que se referia aos saberes. Uma coisa era clara: eu teria que me capacitar, adquirir conhecimento. Sou pai, educador e músico, mas aonde eu queria chegar com os jovens? Ensinar música a eles e montar uma escola de samba? Definitivamente não era isto.

Então comecei a pensar nas futuras ações. Num primeiro momento, procurei contratar uma assistente social e uma psicóloga. Mapeamos a rede escolar, entramos em contato com escolas próximas. Fizemos parcerias com agentes de saúde, já que até então eu levava os meninos informalmente ao meu dentista e ao meu médico. Então começamos, efetivamente, a trabalhar. Registramos o estatuto, que recebeu o último carimbo no dia 12 de outubro de 1997, Dia da Criança. Neste dia nos tornamos pessoa jurídica formal.

Hoje temos quase três mil alunos e, depois de treze anos de trabalho, já passaram por aqui mais de 10 mil crianças. Nosso programa de nutrição serve 29 mil refeições quentes por mês, entre café da manhã, almoço e lanches. Temos como principal população atendida os jovens em situação de vulnerabilidade 
comunicação \& educação • Ano XV • número 2 • maio/ago 2010

social, mas também recebemos crianças de outros níveis socioeconômicos, de todas as raças e credos. Aprendemos a administrar as diferenças. Estamos adequando as instalações também para cadeirantes e crianças especiais. Embora até hoje a adaptação para a circulação deles tenha sido improvisada, até nesse sentido o trabalho é muito positivo, pois mobiliza a todos. As pessoas ajudam, carregam as cadeiras de roda para os lugares aonde eles têm que chegar, sem nenhum tipo de estigma.

Fizemos 87 shows em 2008 e já tocamos na Inglaterra, França e Estados Unidos. Não somos reféns de financiamentos públicos. Temos aplicado a Lei Rouanet, que é renúncia fiscal de governo ligada à cultura, mas buscamos a autossustentabilidade completa. Hoje ela vem, em sua maior parte, do trabalho do Grupo Artístico em apresentações institucionais para empresas, pelo qual pedimos uma contrapartida financeira. Esse é um bom espaço para trabalhar, pois as empresas também desejam ter sua imagem associada à responsabilidade social. Isso se reflete inclusive em parcerias que nos possibilitam oferecer programas e cursos de qualidade. Os Meninos têm acesso aos cursos de inglês da Cultura Inglesa, que é a escola oficial do Conselho Britânico. Os cursos de tecnologia são realizados em parceria com grandes empresas do setor, como Microsoft, Kingston e AMD. Elas constroem os programas conosco, abordando não só a questão técnica, mas também aspectos como trabalhabilidade $\mathrm{e}$ empregabilidade, preparando o jovem para o primeiro emprego. A ideia é que prossiga na escola regular e que aos 16 anos, como o Estatuto da Criança e do Adolescente e a lei permitem, possa ingressar no mercado de trabalho com conhecimento de inglês, tecnologia, computação e outros contextos.

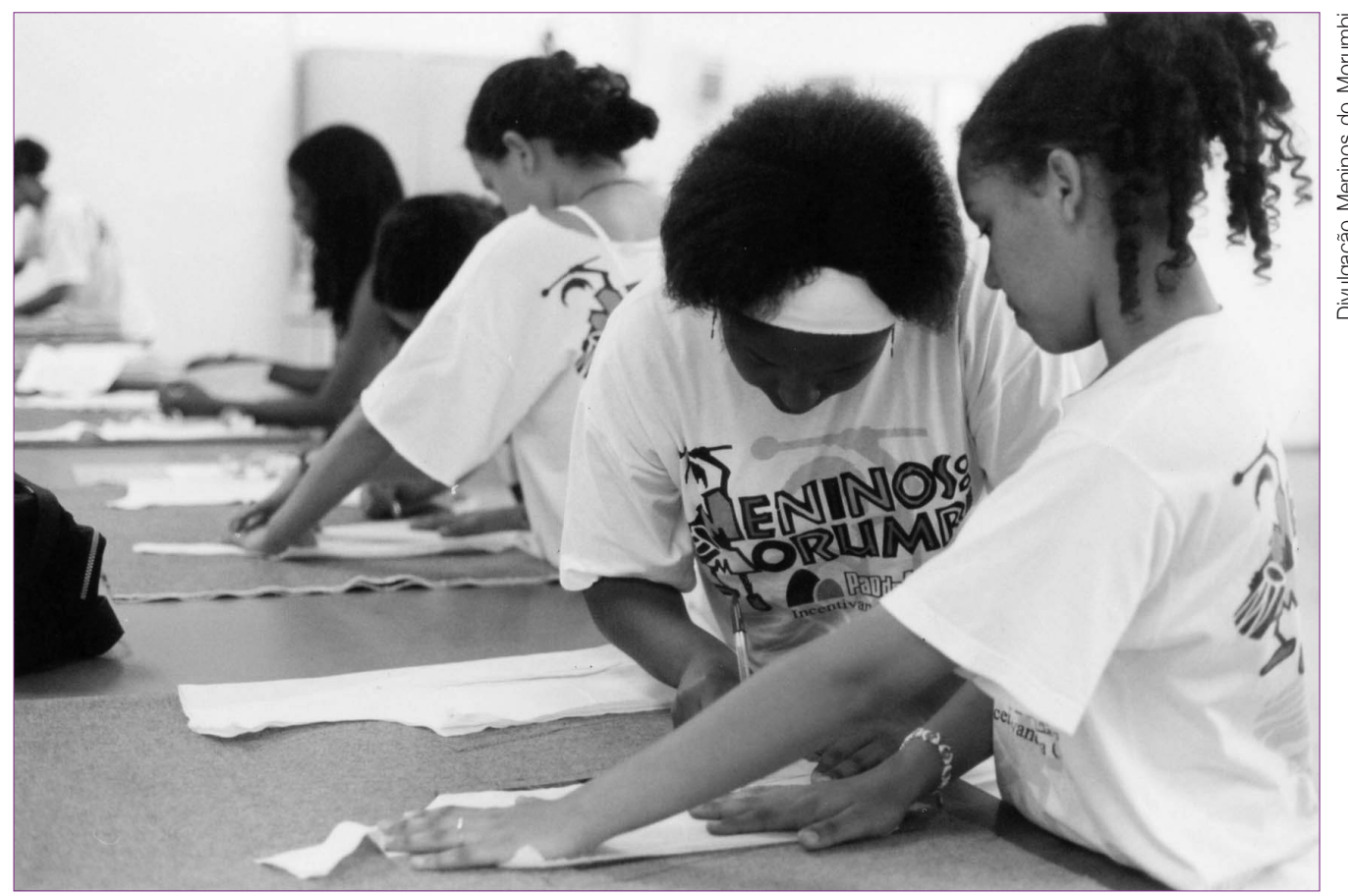

"O que faz você feliz é o dia a dia, o processo, não o objetivo.

A felicidade já está presente quando você trabalha e luta pelo seu sonho." 
Música que forma cidadãos • Flávio Pimenta

A essência e a alma de tudo isso é sempre o grupo artístico, que cria neles identidade e pertencimento. Desenvolvemos um trabalho artístico de muita qualidade, mesmo porque já comecei tomando os cuidados necessários para que a banda pudesse evoluir tecnicamente e ser reconhecida. Isso gera um contexto extremamente sedutor, capaz de fazer com que o jovem esqueça o prazer que a rua oferece. Aqui ele pode exercer sua competência, empreender e protagonizar. O projeto não é meu, não é do governo e não é de uma empresa. O projeto é do jovem integrante. Ele entende que para tocar, dançar, cantar bem, não ser visto como um coitadinho e sim como um músico, dançarino ou cantor com qualidade, tem que trabalhar muito. Sucesso, nesse sentido, é $70 \%$ de trabalho duro e $30 \%$ de talento. O esforço para alcançar a qualidade se reflete depois na maneira de ele entender e enfrentar a vida lá fora.

Este contexto é também um anticorpo natural muito importante com relação à droga, por exemplo. Não temos aqui um discurso tão somente ético ou moral, mas ligado à competência. Não cabe droga ou dependência quando você precisa alcançar metas dentro de um trabalho, e principalmente se realiza esse trabalho com prazer. Um atleta não usa álcool ou drogas porque sabe que isso vai atrapalhar suas metas, às quais ele dá muito valor. Nossos problemas referentes a drogas e violência estão mais ligados aos pais do que aos jovens. Para esse contexto temos parcerias na área da psicologia com a Pontifícia Universidade Católica e com a organização Sedes Sapientiae, oferecendo terapia familiar sob a coordenação da Professora Dra. Rosa Macedo.

É claro que também enfrentamos questões como a vulnerabilidade ao crime e a maternidade precoce, entre outros. Para lidar com elas, nosso maior desafio é entender como a ética e a moral poderão moldar os bons valores na vida e nas comunidades das crianças. Nossa preocupação não é exatamente com a capacitação profissional do jovem. Nosso desejo principal é que aqui ele vivencie os bons valores. Não importa que seja um catador de latinhas na rua, o importante é que saiba a diferença entre as coisas que são boas e ruins. Estabelecer a sua relação com a sociedade, com o outro, se entender cidadão, ser um bom ser humano, é o que priorizamos na educação.

\section{BUSCANDO IDENTIDADES}

A música sempre foi nossa good trap, a boa armadilha. Foi o que atraiu a todos e nos levou à organização dos shows, que eles chamam de balada. Porque para eles é, de fato, uma balada. Eles vão a lugares maravilhosos para tocar, são desejados e aplaudidos, validados fora dos nossos muros. Nós somos uma banda de verdade, com quadra para ensaio, caminhão de equipamentos e ônibus para os músicos. Não poderia ser diferente. A minha fala com eles até hoje é a mesma: eu não sou benemerente, não estou aqui para cuidar de menino pobrezinho, rebelde. Tudo aqui só funciona porque eu peguei o meu projeto de vida e coloquei todo mundo dentro. Eu continuo sendo músico e produtor, tenho minha empresa. Se um dia os jovens não 
comunicação \& educação • Ano XV • número 2 • maio/ago 2010

derem conta de manter o padrão de qualidade musical e o sonho coletivo de sucesso artístico, eu vou cuidar da minha vida, minha música e meus negócios, e eles voltam para casa. É um discurso duro, mas é uma maneira realista de falar com eles. Eu sou um maestro, um band leader. Todos têm uma relação muito próxima e franca comigo, o que permite que eu saiba dos problemas de cada um - desde um pai que está na cadeia até o próprio jovem que está indo para o crime.

Nossa grande luta aqui é contra o crime. Antigamente, dizia-se que a miséria criava o crime. Hoje, é muito tênue a linha que divide a estética do hip hop, do bad boy, do pertencimento ao crime efetivamente. O crime se tornou eixo de vida. $\mathrm{O}$ menino que vive na periferia, num gueto, não enxerga a ponte para sair dali. Teoricamente essas pontes deveriam ser a educação e a família, mas ele vem de gerações que já não foram para a escola. É muito difícil atravessar desse lugar para outro e conquistar a cidadania, entender-se como cidadão de uma maneira ampla, cidadão do mundo, e não do gueto de uma cidade. Aí alguns, a maioria talvez, acaba cedendo ao crime, porque todo jovem quer pertencer a um grupo, ter coisas, ser admirado, desejado. No caminho do crime ele agrega isso à sua vida, passa a ser respeitado, famoso, ter dinheiro e uma identidade, ainda que de maneira equivocada.

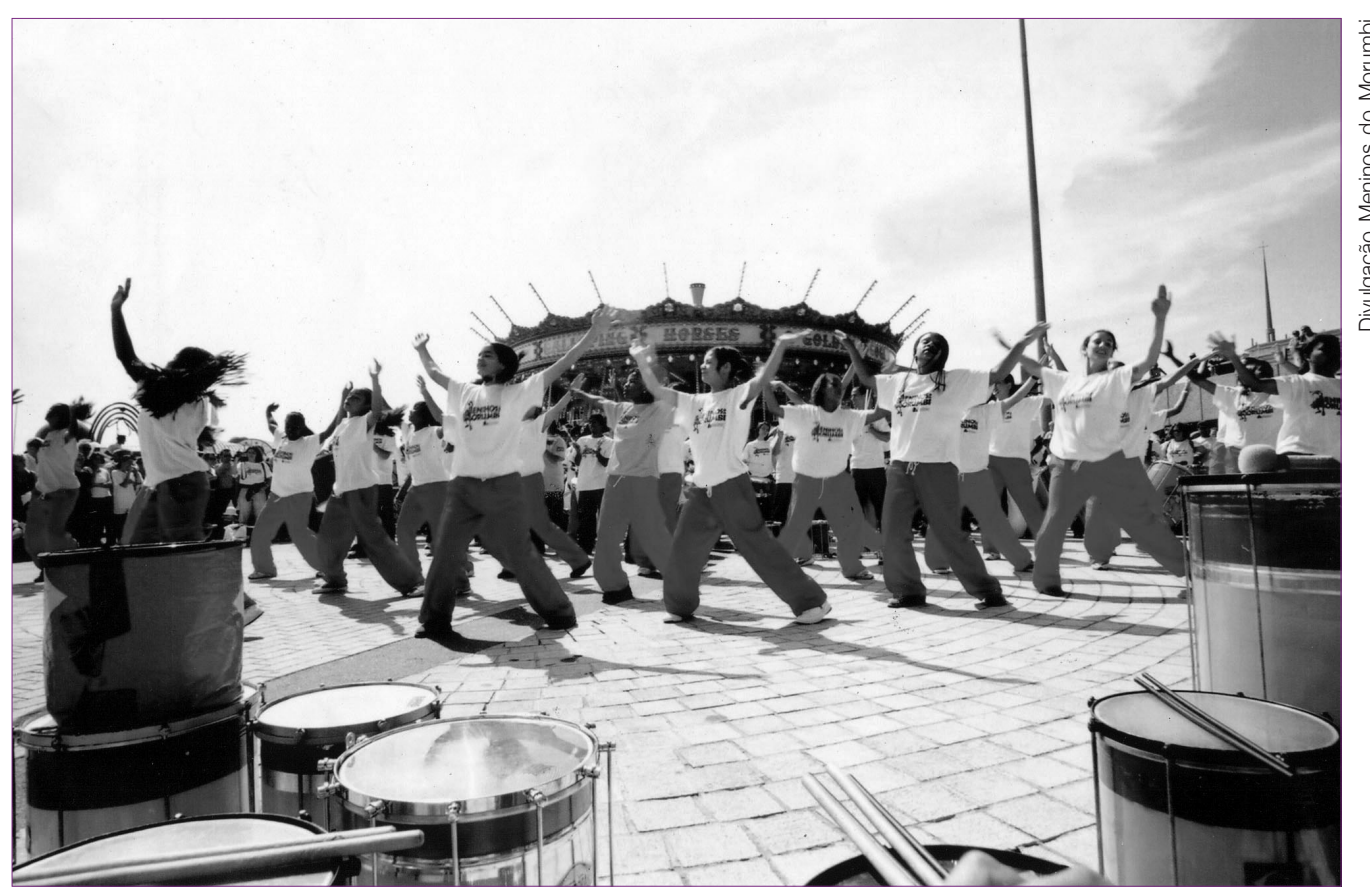

"Pelos Meninos do Morumbi já passaram mais de 10 mil crianças, que se apresentaram em diversos lugares do Brasil, assim como na Inglaterra, França e Estados Unidos."

Outra questão, ainda mais difícil de entender, é que a identidade existente dentro do gueto não se mistura com a identidade de quem está fora dele. Dentro da favela, você morre se roubar um botijão de gás. Já tivemos casos de meninos que arrancaram o fio do orelhão e levaram uma surra do líder da 
favela em praça pública, na frente do pai, da mãe, do avô. Se alguém se meter, morre. E mais tarde, se persistir na conduta, esse mesmo menino é convidado a se mudar da favela para não morrer. Então por que ele sai da favela, desce até bairros ricos, assalta um cidadão de outro nível socioeconômico, volta para a favela sem culpa alguma e lá é muitas vezes enaltecido pelos seus amigos? Porque a identidade no gueto, o sociabilizante, na periferia, muitas vezes é diferente da ideia que temos de cidadania. Todos nós somos cidadãos brasileiros, teoricamente entendemos a sociedade de maneira ampla, mas eles têm uma identidade própria lá dentro. Sinto isto quando um jovem diz que é $100 \%$ favela, ou às vezes até $100 \% P C C^{*}$.

$\mathrm{Eu}$ pergunto o que traria a grande transformação nesse cenário. Nós fizemos um programa com escolas públicas da região nesse sentido. Havia meninos que eram um exemplo de comportamento e iniciativa aqui dentro, mas na escola desrespeitavam todo mundo, tiravam notas baixas, punham bombas no banheiro. Houve até um caso, famoso na imprensa, de um jovem que entrou armado na escola e ameaçou o professor. Depois de muito pensar, achamos que isso estava ocorrendo porque aqui, no Meninos do Morumbi, há um sentimento de pertencimento, algo que eles agregam à sua identidade, e nas escolas não. Então planejamos um festival de música em que os meninos poderiam montar bandas com os amigos que quisessem, mas deveriam obrigatoriamente convidar um funcionário da escola, de qualquer escalão, e um familiar de primeiro ou de segundo grau. Deveriam também compor e interpretar uma música de qualquer gênero, tendo como tema a própria escola e a história dela.

O festival também contemplava dança e artes. Convidamos os professores para fazer oficinas de criação e composição em nossa sede. Depois das oficinas, os professores voltaram à escola para trabalhar com os alunos. Foram obrigados a negociar as diferenças: se algum aluno queria colocar na música um verso ofensivo à escola, por exemplo, o professor conversava, propunha substituições. Dessa forma, todos começaram a administrar o trabalho juntos. $\mathrm{O}$ resultado do Festival foi lindo, gerando uma centena de canções sobre a escola. E fez com que os meninos trabalhassem com o professor da mesma forma que trabalham aqui no Meninos do Morumbi. Todos tiveram que dar as mãos e se relacionar.

Volto a pensar na favela, na periferia, e imagino o que é que falta lá. Diz-se que falta a presença da sociedade. As pessoas falam em sociedade na terceira pessoa, não se colocam como parte dela. Acham que a sociedade fica do outro lado da rua. "Falta a presença do Estado", dizem também. Na minha opinião, o que mais falta na favela são bons valores. E valor não se ensina, se vivencia. As pessoas aprendem valores nos ambientes em que estão, na convivência com os pais, com os amigos, na escola. Ninguém está dizendo o tempo todo a elas: "Isso é bom, isso é mau. Não dê tiro nos outros, porque isso é ruim". Da mesma forma, você não vai conseguir atrair um menino de rua dizendo a ele: "Vou ensinar Windows XP para você e vou salvar sua vida". Eu não acho
* PCC - sigla para Primeiro Comando da Capital, facção criminosa criada na década de 1990 e responsável pela organização de diversas rebeliões em presídios paulistas a partir daí. (N.E.) 
comunicação \& educação • Ano XV • número 2 • maio/ago 2010

que alguém na periferia ou na favela queira ser salvo. Acho que a minha experiência com os meninos funciona porque tem a ver com compartilhar. $\mathrm{O}$ que eu fiz foi compartilhar, estabelecer uma via de duas mãos. Eu continuo sendo músico, adoro tocar com eles, viajar com eles, produzir e compor. O que fiz foi perceber a força que a minha arte tem em transformar a vida do outro e compartilhar. Isso fez a diferença inclusive na minha vida.

Na favela o que falta é a presença de todos nós. Falta o cidadão tomar para si as ações que possam melhorar a vida dos menos favorecidos. Os jovens não têm em quem se espelhar. Eu tive uma mãe sempre presente e um pai maravilhoso. Ele era economista, presidente de empresa, porém começou a vida como camponês. Eu me espelhei nos meus pais. Desde a infância, todos nós precisamos de bons exemplos. No gueto, na periferia, o jovem muitas vezes não tem em quem se espelhar. Proporcionar isso a ele é fundamental. Todo cidadão deveria procurar compartilhar o seu melhor com o outro e nunca oferecer restos.

Eu não acredito em assistencialismo a não ser para apagar incêndios. Quando preciso, algumas vezes nós desenvolvemos ações também nesse sentido. Por exemplo, se visitamos um barraco cheio de ratos e com um buraco no teto, onde mora uma mulher sozinha com filhos, sem cama, fogão ou bujão de gás e sem nada na geladeira, nós fazemos uma compra de supermercado, colocamos o gás, arrumamos a geladeira e o telhado e eliminamos os ratos. A criança pequena nós colocamos na creche, os maiores na escola e todos nos cursos que oferecemos. Ajudamos por meio de nossa rede a arrumar trabalho para ela, nem que seja de diarista. Daí em diante, a nossa parte acabou. Ela terá que buscar seu futuro e começar uma nova história. Nesse sentido eu acredito no assistencialismo. Mas quando você está na porta da sua casa, alguém toca a campainha pedindo ajuda, você pega a sua roupa velha ou restos de comida e dá a essa pessoa, muitas vezes você cria um estigma. Acho que a esmola ou mata de vergonha ou vicia, como diz a música de Luiz Gonzaga. Ações que não ajudam o outro a sair do lugar podem fazer nossa catarse, porém perpetuam nossa herança escravista. É como se os miseráveis existissem para validar os ricos.

\section{O VERDADEIRO OBJETIVO ESTÁ NO CAMINHO PARA REALIZAR}

As atividades das crianças aqui, como a música e os cursos que oferecemos, muitas vezes são o primeiro momento em que elas dão-se conta sozinhas de suas atividades, sem a ajuda do pai e da mãe. Eles se sociabilizam, empreendem, protagonizam. Sabem que, quanto maior for o valor que agregarem ao grupo artístico tecnicamente, maior será o valor que poderemos pedir em contrapartida pelas apresentações, e esse recurso pagará o funcionário, a conta de água e de luz. Isto tudo tem a ver com pertencimento e identidade. 


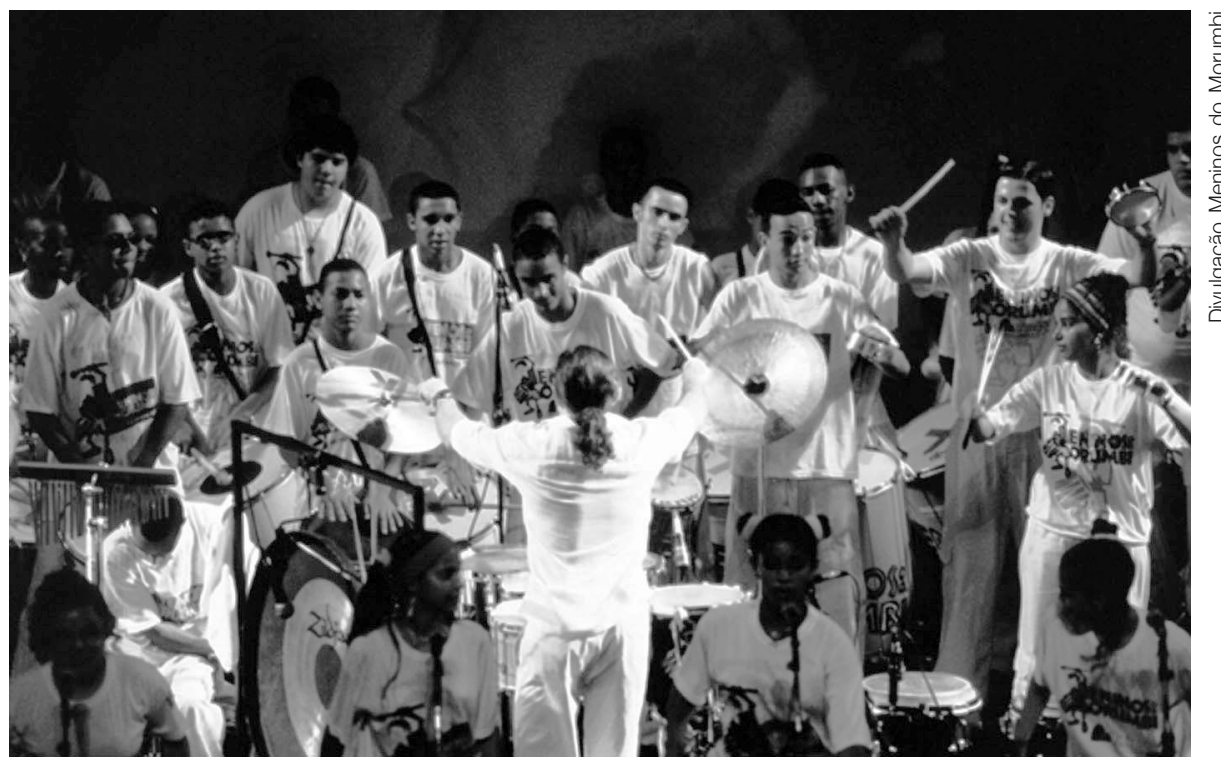

"O jovem entende que, para tocar, dançar, cantar bem, tem que trabalhar muito. O esforço para alcançar a qualidade se reflete depois na maneira de ele entender e enfrentar a vida lá fora."

Quando recebemos a visita do Collin Powell, Secretário de Estado dos Estados Unidos no Governo Bush, ele se sentou para conversar com trinta jovens. Esses jovens perguntaram, entre outras questões muito interessantes, se ele havia sofrido preconceito por ser negro. E ele contou aos meninos a própria história. Ele é descendente de imigrantes jamaicanos, teve uma infância pobre e entrou para o exército durante os últimos anos do apartheid, que existia inclusive dentro do exército americano. Revelou que havia trabalhado como faxineiro numa fábrica de refrigerantes e que, há cinquenta anos, não imaginava que se tornaria Secretário de Estado dos Estados Unidos. Narrou um episódio que viveu ainda como faxineiro, quando derrubou uma pilha de garrafas e passou a noite limpando tudo sozinho. Na manhã do dia seguinte, o encarregado ficou impressionado com o trabalho e deu a ele uma promoção.

Quando ele contou essa história, os olhos dos meninos brilharam. A mensagem que ficou para eles é que qualquer um que luta pode alcançar o sucesso ou, minimamente, uma vida melhor. Pode-se dizer: "Ah, mas ele alcançou isto nos Estados Unidos, no Brasil as chances são diferentes”. Não se pode pensar que somente se é feliz quando alcançamos objetivos. É preciso ter um norte, buscar os sonhos, mas o mais importante é caminhar para ele. Quando eu era moleque e comecei meus estudos em música, não queria ser exatamente músico, queria ser pop star. Com o tempo, descobri que tocar era minha grande paixão e isso já me tornava feliz.

O que faz você feliz é o dia a dia, o processo, não o objetivo. A felicidade já está presente quando você trabalha e luta pelo seu sonho. Eu descobri também o quanto passei a ser feliz quando compartilhei minha música e meus sonhos com as crianças. Nós somos felizes aqui. 


\section{O papel do educador e da escola no despertar da consciência}

Não importa quem é, como vive, o que pensa, o que fez ou o que decidiu para si: onde há um ser humano há uma luz a ser cuidada, um afeto a ser sentido, um corpo a ser identificado. "Isso é educar", defende o filósofo, teólogo e psicólogo, Jorge

Trevisol. "Educar é (re)despertar a dignidade presente em cada ser, tantas vezes ignorada por nossa sociedade."

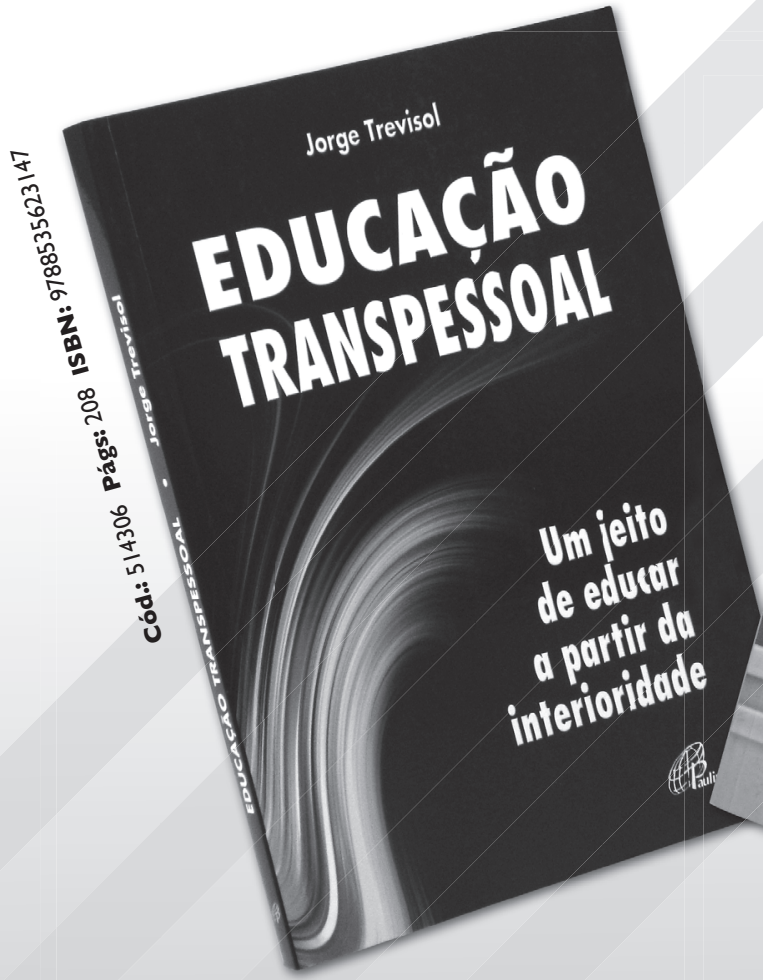

Educação transpessoal

Um jeito de educar a partir da interioridade

Educar a partir de dentro, da consciência do profundo, das motivações internas, do sagrado que habita o coração, alargando o espaço e a compreensão de si mesmo. Professor Trevisol sugere um novo jeito de cuidar do ser, um jeito que vá além do pessoal, que sinta mais do que pense, que escute mais do que fale, que seja mais humano que técnico, mais compassivo que juiz, mais esperançoso e preventivo que pragmático, enfim uma educação abrangente, transdisciplinar e transcendente. Educar assim exige desprendimento, entrega, humildade e confiança, a fim de modificar o modo de se perceber além dos sentimentos, naquele espaço em que não haverá nem pensamentos nem sensações nem comportamentos, somente o essencialmente sagrado e puro: a inteireza de tudo.

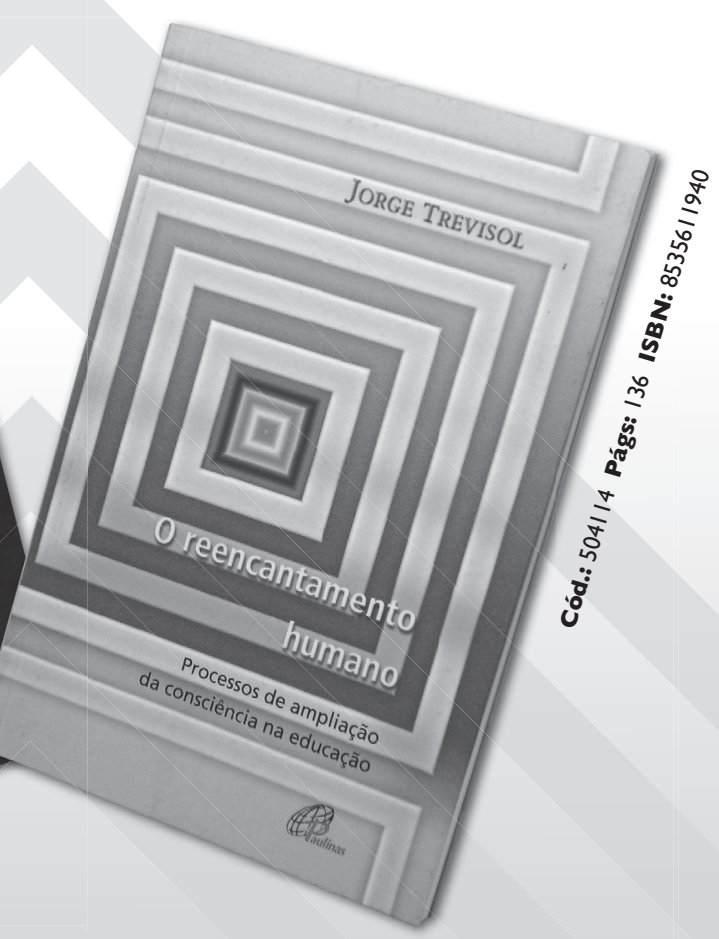

O reencantamento humano Processos de ampliação da consciência na educação

Como consequência de processos de ampliação da consciência na educação, Trevisol desafia os que pensam e fazem educação a uma releitura da obra de Morin, Os setes saberes necessários à educação do futuro, a partir de uma reflexão de cunho existencial e educacional, instigada pelo questionamento: sete saberes ou sete consciências? Neste sentido, explora cada um dos sete saberes como possíveis organizadores da consciência, ou níveis diferentes de consciência, que, se bem compreendidos e aplicados, são propiciadores de autoconhecimento. Sua crença é que o processo educativo contribui para ampliar os diferentes níveis de consciência, mediados por nova intuição e novo conhecimento construídos para se tornarem vida no indivíduo que os experimenta. 